\title{
Structural and functional alterations in photosynthetic apparatus of plants under cadmium stress
}

\author{
Pooja Parmar, Nilima Kumari and Vinay Sharma*
}

\begin{abstract}
Cadmium is a potentially toxic heavy metal that hampers plant productivity by interfering with their photochemistry. $\mathrm{Cd}$ causes disturbances in a range of physiological processes of plants such as photosynthesis, water relations, ion metabolism and mineral uptake. Cd pronouncedly affects photosynthesis by alteration of its vital machinery in all aspects. Photosynthesis is a well organised and sequential process fundamental to all green plants and microorganisms which involves various components, including photosynthetic pigments and photosystems, the electron transport system and $\mathrm{CO}_{2}$ reduction pathways. Any damage at any level caused by $\mathrm{Cd}$, critically affects overall photosynthetic capacity. Present review focuses on key effects of $\mathrm{Cd}$ on photosynthetic apparatus including chloroplast structure, photosynthetic pigments, Chl-protein complexes and photosystems resulting in overall decrease in efficiency of carbon assimilation pathway.
\end{abstract}

Keywords: Cadmium; Photosynthesis; Chlorophyll; Chloroplast; PSII; PSI

\section{Review \\ Introduction}

The unprecedented increase in heavy metal pollution has become a matter of major concern over the globe (Jamali et al. 2007). Cadmium (Cd) stands 7th out of the 20 toxins and has no known biological function except in marine diatoms (Morel 2008). Cd is used and traded internationally as a metal and as a chemical compound throughout Asia, America, Europe, Australia and Africa (UNEP 2010). Indeed, Cd concentration is progressively increasing at an alarming rate ( 7 to 43 percent over the period of 100 years) in several European countries such as Austria, Denmark, Finland, Greece, Ireland and the United Kingdom (UNEP 2010). It has been estimated that major source of $\mathrm{Cd}$ release into the air are the production of nonferrous metals followed by iron and steel production, fossil fuel combustion, cement production and waste incineration (Pacyna and Pacyna 2001). Cd is constantly added and gets accumulated to the plough layer of soil through various natural and anthropogenic activities such as volcanic eruptions, mining, smelting,

* Correspondence: vinaysharma30@yahoo.co.uk

Department of Bioscience and Biotechnology, Banasthali University, P.O. Banasthali Vidyapith, Rajasthan -304022, India mismanagement of industrial waste and use of phosphate fertilizers (Grant 2011) and its addition to the arable land is a widely recognised problem. $\mathrm{Cd}$ is potentially toxic to all organisms including plants, animals and humans as well. Cd exposure, for instance, is associated with cancers of the prostate, lungs and testes, kidney tubule damages, rhinitis, emphysema, osteomalacia and bone fractures in humans (Nawrot et al. 2006). In plants, it results in many toxic symptoms such as inhibition of growth and photosynthesis, activation or inhibition of enzymes, disturbances in plant-water relations and ion metabolism, and formation of free radicals (Valentoviova et al. 2010).

Phytotoxicity induced by $\mathrm{Cd}$ has been well established and comprehensively studied (Wahid et al. 2009). Cd is taken up by roots through plasma membrane transporters such as ZIP (ZRT-IRT like protein; Zinc regulated transporter, Iron-regulated transporter) and NRAMP (natural resistance associated macrophage protein) in competition to the essential nutrients of plants (Kim et al. 2002) and consequently it is translocated to shoots thereby leading to growth diminution which in due part emanates from disturbed photosynthesis (Bazzaz et al. 1974). Figure 1 illustrates the effects of $\mathrm{Cd}$ as a potent inhibitor of photosynthesis. Photosynthesis inhibition may be attributed to 


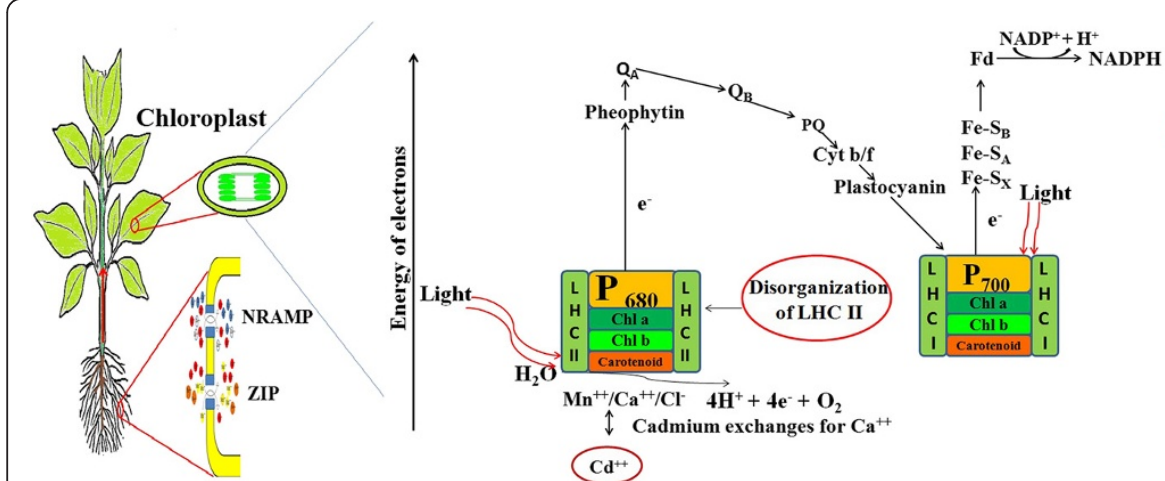

(a) (b)

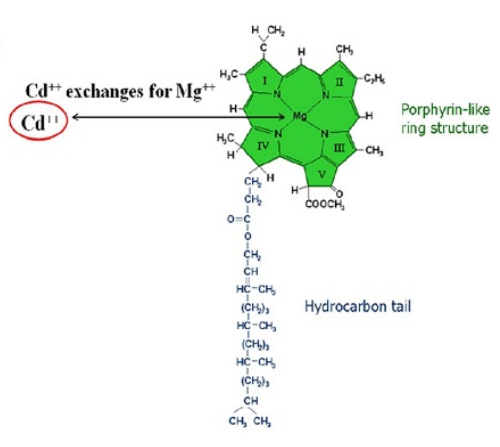

(c)

Figure 1 An overview of effects of Cd exposure to plants at different levels in photosynthetic machinery. (a) Cd uptake in cells through plasma membrane transporters. (b) Alteration in organisation of oxygen evolving and light harvesting complexes, $\mathrm{Cd}$ also binds with $\mathrm{Q}_{B}$ pocket thus slows down electron flow from $\mathrm{Q}_{A}$ to $\mathrm{Q}_{B}$. (c) Incorporation of $\mathrm{Cd}$ in chlorophyll molecule.

diminished chlorophyll biosynthesis (Shukla et al. 2008), interrupted $\mathrm{O}_{2}$ - evolving reactions of PSII and altered electron flow around PSI and PSII (Mallick and Mohn 2003). Cd hampers Calvin cycle by slowing down activity of various enzymes hence resulting in decreased photosynthesis (Ying et al. 2010). Cd has also been known to show inhibitory effect on various enzymes such as ribulose-1,5-biphosphate carboxylase oxygenase (Mobin and Khan 2007), phosphoenolpyruvate carboxylase (Latif 2008), aldolase (Sheoran et al. 1990), fructose-6-phosphate kinase (Malik et al. 1992), fructose-1,6-bisphosphatase (Sheoran et al. 1990), NADP ${ }^{+}$. glyceraldehyde-3-phosphate dehydrogenase (Sheoran et al. 1990) and carbonic anhydrase (Mobin and Khan 2007).

Stomatal closure due to entry of $\mathrm{Cd}$ into the guard cells in competition to $\mathrm{Ca}^{+2}$ (Perfus-Barbeoch et al. 2002) and reduction in stomata count per unit area are also characteristic symptoms of $\mathrm{Cd}$ stress resulting in lesser conductance to $\mathrm{CO}_{2}$ (Pietrini et al. 2010) which consequently leads to overall inhibition of photosynthesis.

The present review is an attempt to develop an orchestrated understanding of the mechanisms involved in altering and damaging various components of photosynthetic machinery by $\mathrm{Cd}$ thereby leading to effective loss in the anabolic reactions of plants.

\section{Photosynthetic machinery under Cd stress Chloroplast structure}

$\mathrm{Cd}$ convincingly resulted in marked distortion of chloroplast ultrastructure leading to disturbed shape and inflated thylakoids (Najeeb et al. 2011). Chloroplast structure disturbance has been partly manifested by a notable decrease in chloroplast number and size, grana stacking, starch grain content and accumulation of plastoglobuli observed in various plants such as Picris divarticata $(75 \mu \mathrm{M}, 14$ days after treatment (DAT)), Hordeum vulgare (5 $\mu \mathrm{M}, 15$ DAT) and Brassica (Ying et al. 2010; Wang et al. 2011; Elhiti et al. 2012). Further, plants show differential aggregation of grana in young and older leaves. For instance in willow, older leaves showed swollen but organised thylakoids whereas young leaves appear to be more dense structured accompanied by tannin precipitation. Reed plant chloroplasts displayed a disturbed shape, wavy appearance of grana and stroma thylakoids and swollen intra thylakoidal space owing to lipid peroxidation, a consequence of increased lipid accumulation in thylakoids (Hakmaouia et al. 2007).

Disruption in chloroplast structure is also ensued due to increased peroxidation of membrane fatty acid and lipid contents resulting from enhanced lipooxygenase (LOX) activity (Remans 2010). LOX mediates polyunsaturated fatty acid oxidation including chloroplast membrane lipids such as monogalactosyldiacyl-glycerol (MGDG), digalactosyldiacyl-glycerol (DGDG) and phosphatidyl glycerol (PG) hence resulting in production of free radicals. LOX activity has been positively correlated with increased lipid peroxidation in plants such as Arabidopsis, Barley, Lupine and Phaseolus under Cd stress (Maksymiec and Krupa 2006; Tamas et al. 2009). A significant decrease has also been reported in the content of polaracyl lipids especially MGDG, DGDG and PG in tomato chloroplasts membranes (Djebali et al. 2005) which is considered to be indispensable for maintenance of membrane integrity.

Grana disorganization can be attributed to reduced MGDG level, as well as the decrease in 16:1 trans fatty acid content in MGDG and PG. In Brassica napus (50 $\mu \mathrm{M}, 15$ DAT) leaves, remarkable decrease upto $80-84 \%$ was observed in DGDG and MGDG respectively (Nouairi et al. 2005), which may possibly be a reason in disintegrated grana.

\section{Cd induced pigment changes}

Among the photosynthetic pigments enormous studies have been conducted till date on reduction in chlorophyll and carotenoids in plants exposed to $\mathrm{Cd}$ stress. Chlorophyll destruction in older leaves and its biosynthesis inhibition in 
newer ones have been known to be prime cause in leaf chlorosis in plants growing in Cd treated soils (Xue et al. 2013). Inhibition of chlorophyll biosynthesis enzymes and activation of its enzymatic degradation plays crucial role in net loss in chlorophyll content (Somashekaraiah 1992).

Aminolevulinate (ALA) is a crucial compound in chlorophyll biosynthesis and its synthesis is the rate-limiting and regulatory step. Cd inhibits ALA synthesis at the site of availability of glutamate for ALA synthesis and interferes by interacting with $\mathrm{SH}$ group of enzymes, $\delta$-aminolevulinic acid dehydratase (Mysliwa-Kurdziel and Strzalka 2002) and porphobilinogen deaminase, (Skrebsky et al. 2008) leading to the accumulation of chlorophyll biosynthesis intermediates like ALA and porphyrins. In fact ALA accumulation is considered to be a reason for generation of reactive oxygen species which alters redox status of plants and thus disturbing plant homeostasis as reported in Soybean (0$100 \mu \mathrm{M}, 10 \mathrm{DAT})$ and Cucumis (0-1000 $\mu \mathrm{M}, 10 \mathrm{DAT})$ (Noriega et al. 2007; Goncalves et al. 2009). Additionally $\mathrm{Cd}$ reacts with protochlorophillide reductase, which causes photoreduction of protochlorophillide into chlorophyllide thus diminishing the raw material for chlorophyll synthesis (Stobart et al. 1985).

$\mathrm{Cd}$ also decreases uptake of nutrients such as $\mathrm{Mn}, \mathrm{Fe}$ and $\mathrm{Mg}$, hence a comparatively higher amount of cellular Cd interferes with $\mathrm{Mg}^{2+}$ insertion into protoporphyrinogen or may cause Chl destruction as consequence of $\mathrm{Mg}^{2+}$ substitution in both Chl a and b (Gillet et al. 2006).

Carotenoid content in plants exposed to $\mathrm{Cd}$ do not exhibit a set pattern and may either increase or decrease. The increase has been observed in many cases as in Cucumis sativus L. (Burzynski et al. 2007) and Zea mays L. (100 $\mu \mathrm{M}, 10$ DAT) (Chaneva et al. 2010). On the contrary decrease was also observed in a few cases e.g. Pisum sativum (7 mg/kg, 20 DAT) (Hattab et al. 2009). Other leaf pigments including neoxanthin, lutein, violaxanthin were found to decrease in Lycopersicon esculentum and Spinacea oleracea plants (López-Millán et al. 2009; Fagioni et al. 2009).

In lower organisms, $\mathrm{Cd}$ exposure caused a significant drop in the amounts of phycobiliprotein viz. allophycocyanin, phycocyanin, and phycoerythrin e.g. Chlamydomonas (50 $\mu \mathrm{M}$, for $24 \mathrm{hrs})$, Gracilaria $(300 \mu \mathrm{M}, 16 \mathrm{DAT})$ and Hypnea musciformis $(300 \mu \mathrm{M}, 7 \mathrm{DAT})$ that led to decrease in photosynthetic efficiency (Perrault et al. 2011; Santos et al. 2012; Bouzon et al. 2012).

\section{Cd induced changes in chlorophyll-proteins complexes}

Chl-proteins can be described as $\mathrm{Chl}$ a and $\mathrm{Chl} \mathrm{a} / \mathrm{b}$ multicofactor proteins for both photosystems (PS) bound to chlorophylls and carotenoids (Fromme et al. 2001). Cd effects on both the PS as well as degree of damage vary in the plant species even among cultivars and populations, depending on genotypic and ecotypic differences (Prasad 1995).

PSII core complex Immunoblotting of Chl-protein complexes did not depict any changes in the level of polypeptides of PSII complexes comprising of CP 47, CP 43, D1 and D2 under Cd stress as demonstrated in rice $(75 \mu \mathrm{M}$ Cd, 28 DAT) and spinach (100 $\mu \mathrm{M}$ Cd, 30 DAT) (Pagliano et al. 2006; Fagioni et al. 2009). The same pattern was also observed in lower organisms i.e. Chlamydomonas reinhardtii ( $50 \mu \mathrm{M}$, for $24 \mathrm{hrs}$ ) too (Perreault et al. 2011).

$\mathrm{Cd}$ toxicity may be attributed to both acceptor and donor side of PSII thus preventing photoactivation (Sigfridsson et al. 2004). On the donor side due to high affinity, $\mathrm{Cd}$ exchanges with $\mathrm{Ca}^{++}$in $\mathrm{Mn}^{++} / \mathrm{Ca}^{++}$cofactor present in oxygen evolving complex (Faller et al. 2005; Pagliano et al. 2006); the exchange leads to reduced kinetics of Hill reaction. On acceptor side $\mathrm{Cd}$ decreased the rate of electron transfer from $\mathrm{Q}_{\mathrm{A}}$ to $\mathrm{Q}_{\mathrm{B}}$ due to interaction with nonheme Fe and conformational modification of $\mathrm{Q}_{\mathrm{B}}$ pocket (Geiken et al. 1998).

Further decrease in lipid content in chloroplasts specifically MGDG and DGDG (Nouairi et al. 2005), considered to be indispensable for PSII activity, causes structural disorganisation of PSII supramolecular structure (Quartacci et al. 2000).

Light harvesting complex (LHC) II LHCII is the principle light harvesting pigment-protein complex of PSII which absorbs light energy and transfers it to the reaction centre. The native form of LHCII is a trimer composed of three Lhcb proteins: Lhcb1, Lhcb2 and Lhcb3 (Lucinski and Jackowski 2006). These LHCII aggregates play dynamic role in triggering the thermal dissipation of extra energy for efficient excitation quenching and display photoprotective role in case of overexcitation of reaction centre and antenna (Barros et al. 2009). Cd exposure results in dissipation of total mass of Lhcb1 and Lhcb2 and accounts for disorganization of trimer-forming monomers resulting in diminished LHCII aggregation complexes. This was indicated by infrared studies on Secale cereale exposed to $\mathrm{Cd}(50 \mu \mathrm{M}, 7 \mathrm{DAT})$ where aggregate/trimeric ratio remained $73 \%$ of the control (Janik et al. 2010). Cd toxicity resulted in constrained dissipation of excitation energy which may have been induced by alterations in the quenching centre formation or inhibition of vibrational transfer of thermal energy between pigments and the protein skeleton (Gruszecki et al. 2009). In Spinacia oleracea L. Lhcb1.1 isomers of Lhcb1 were highly affected even in small exposure to stress ( $75 \mu \mathrm{M}, 5 \mathrm{DAT})$ whereas others i.e. Lhcb2 and Lhcb3 were less affected (Fagioni et al. 2009). Differential level of expression in Lhcb2 was observed in case of two ecotypes of Sedum (hyperaccumulating 
and non-hyperaccumulating) which suggested temporal regulation of gene expression. Upon 24 hrs of Cd $(2 \mu \mathrm{M})$ treatment non-hyperaccumulating ecotype exhibited higher expression level than hyperaccumulating, followed by a reversal of the situation after 8 days (Zhang et al. 2011).

Proteomic studies on Oryza sativa L. (7.5-75 $\mu \mathrm{M}, 24$ DAT) suggested contrasting results where LHCII content is not adversely affected suggesting that antenna complexes of PSII are less affected (Pagliano et al. 2006).

Lipid profiling of chloroplast is conducive to suggest that decrease in 16:1 trans fatty acid content in MGDG and PG, diminished LHCII oligomerization due to its specific binding in sn-2 position in the chloroplastic PG (Vassilev et al. 2004). Cadmium due to its high affinity gets substituted in pigment protein complexes causing conformational changes (Küpper et al. 2002) leading to incorrect binding of chlorophyll molecule to the protein matrix.

PSI core complexes In some plants exposed to cadmium stress PSI instead of PSII is the prime site of damage. Previous studies suggested that $\mathrm{Cd}$ induced iron deficiency in cell organelles is possibly a reason for greater damage to PSI (Siedlecka and Baszyński 1993; Timperio et al. 2007). Prolonged deficiency of iron resulted in generation of reactive oxygen species in thylakoids which principally destroys iron-sulphur centres (PSI) and Lhca antennae (Michel and Pistorius 2004). In fact, observations suggesting damage to PSI have been reported in Cucumis sativus L. (10 $\mu \mathrm{M}, 35 \mathrm{DAT})$ (Sárvári 2005; Sárvári et al. 2008) and wheat (Atal et al. 1991). However in Pisum sativum extended stress treatment of Cd (0-10 mM, 12 DAT) led to equal damage to both PSI and PSII (Chugh and Sawhney 1999).

Proteomic and expression studies conducted on basal leaves of Spinacia oleracea L. (100 $\mu \mathrm{M}, 0-15$ DAT) revealed presence of modified amino acids in polypeptide chains of PsaA/PsaB proteins corroborating the accumulation of incomplete monomeric units leading to disruption of PSI supercomplexes, reaction centre I and LHCI (Fagioni et al. 2009).

\section{Cadmium induced changes in photosynthetic yield}

The main effect of $\mathrm{Cd}$, studied to date is hampering the photochemical activity of both PSI and PSII. The reports regarding this have always been contradictory in deciding the principal site of damage i.e. PSI or PSII. As observed in peas, $\mathrm{Cd}$ affects both the photosystems over a long period of stress (Chugh and Sawhney 1999). However, during initial stages $\mathrm{Cd}$ had more pronounced effect on the activity of PSII as observed in Thalspi caerulescence (Kupper et al. 2007) stating higher sensitivity of PSII to Cd toxicity (Wang et al. 2013).

The chlorophyll fluorescence induction parameters represent the use of non-invasive tool to understand the photosynthetic performance in vivo and to assess effects of stress on plants photochemistry (Baker et al. 2008). Table 1 depicts effects of $\mathrm{Cd}$ on some of the photosynthetic parameters [Chl (chlorophyll content), Fv/Fm (maximum quantum efficiency of PSII) and $\mathrm{P}_{\mathrm{N}}$ (Net photosynthetic rate)] which reflect lesions in plants photosynthetic yield as a consequence of damage to the photosystems and pigments (Wang et al. 2009). It is evident from the Table 1 that $\mathrm{Cd}$ decreased chlorophyll content, $\mathrm{F}_{\mathrm{V}} / \mathrm{F}_{\mathrm{M}}$ and $\mathrm{P}_{\mathrm{N}}$ indicating impeded photosynthesis. However, PSII disruption as a consequence of $\mathrm{Cd}$ toxicity is reported to depend on the irradiance conditions. During high light intensity, direct damage to the PSII reaction centre occurs instead; this was termed as the 'sun reaction'. On the contrary, LHCII disruption due to exchange of $\mathrm{Mg}^{2+}$ with $\mathrm{Cd}$ in chlorophyll pigment is the prime cause of diminished PSII activity during dark phase and is referred as 'shade reaction' (Kupper et al. 2007).

Comparatively less information is known to us in case of PSI but still data exists which shows higher sensitivity to PSI photochemistry as in Pisum sativum plants (Wodala et al. 2012).

Table 1 Effects of Cd on photosynthetic parameters ${ }^{1}$

\begin{tabular}{|c|c|c|c|c|c|c|}
\hline \multirow[t]{2}{*}{ Plant species } & \multirow{2}{*}{$\begin{array}{c}\mathrm{Cd} \\
\text { concentration }\end{array}$} & \multicolumn{4}{|c|}{$\%$ inhibition } & \multirow[t]{2}{*}{ Reference } \\
\hline & & $\mathrm{Chl} \mathrm{a}$ & Chl b & $\mathrm{Fv} / \mathrm{Fm}$ & Pn & \\
\hline Pisum sativum & $6 \mathrm{mM}, 7 \mathrm{DAT}$ & 31.00 & 32.30 & $-^{*}$ & 79.90 & Januškaitienè, 2012 \\
\hline Picris divarticata & $75 \mu \mathrm{M}, 10 \mathrm{DAT}$ & 10.84 & 1.29 & $-{ }^{*}$ & 44.20 & Ying et al. 2010 \\
\hline Zea mays & $20 \mu \mathrm{M}, 7$ DAT & 36.71 & 37.93 & 3.76 & 13.00 & Wang et al. 2009 \\
\hline Ricinus communis & $50 \mu \mathrm{M}, 12 \mathrm{DAT}$ & 27.30 & 16.70 & 5.00 & 47.00 & Liu et al. 2011 \\
\hline Lycopersicon esculentum & $100 \mu \mathrm{M}, 12 \mathrm{DAT}$ & 35.00 & 23.00 & 2.47 & 73.00 & López-Millán et al. 2009 \\
\hline Cucumis sativus & $50 \mu \mathrm{M}, 48 \mathrm{hrs}$ & 13.89 & 24.44 & 1.57 & 73.00 & Burzynski \& Zurek, 2007 \\
\hline Phragmites australis & $100 \mu \mathrm{M}, 21 \mathrm{DAT}$ & 52.30 & 73.00 & 1.28 & 40.88 & Pietrini et al. 2003 \\
\hline
\end{tabular}

* Values are not available.

${ }^{1}$ Effective concentration of $\mathrm{Cd}$ causing reduction in chlorophyll pigments viz. $\mathrm{Chl}$ a and $\mathrm{Chl} \mathrm{b}$ and non-invasive parameters viz. photosynthetic yield (Fv/Fm) and net $\mathrm{CO}_{2}$ assimilation rate $(\mathrm{Pn})$. 


\section{Conclusion}

In conclusion, $\mathrm{Cd}$ affects photosynthesis either directly or indirectly thus decreasing the crop yield. We reviewed its inhibitory effect on pigments, lipids, photosystems proteins and chloroplasts. Summing up all we investigated net loss in photosynthesis. It can be said that much has been known about Cd toxicity to plants but numerous mechanisms remains debatable about its interaction with photosynthetic proteins i.e. D1 and D2 and oxygen evolving complexes. In particular, we should extend our knowledge towards PSI measurements to get an intricate knowledge on effect of $\mathrm{Cd}$ on photosynthesis. Strategies must be evolved on understanding the mechanism of Cd hyperaccumulation to uphold various phytoremediation strategies.

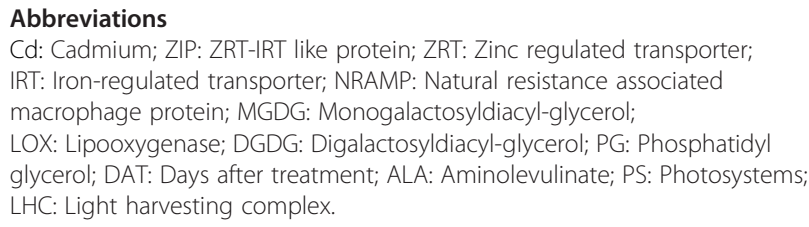

Abbreviations

Cd: Cadmium; ZIP: ZRT-IRT like protein; ZRT: Zinc regulated transporter; IRT: Iron-regulated transporter; NRAMP: Natural resistance associated macrophage protein; MGDG: Monogalactosyldiacyl-glycerol; LOX: Lipooxygenase; DGDG: Digalactosyldiacyl-glycerol; PG: Phosphatidyl glycerol; DAT: Days after treatment; ALA: Aminolevulinate; PS: Photosystems; LHC: Light harvesting complex.

\section{Competing interests}

The authors declare that they have no competing interests.

\section{Authors' contributions}

PP and NK surveyed the literature and prepared the draft. VS provided guidelines for the review, modified and wrote the final version. All authors read and approved the final manuscript.

Received: 26 August 2013 Accepted: 1 October 2013

Published: 8 October 2013

\section{References}

Atal N, Saradhi PP, Mohanty P (1991) Inhibition of the chloroplast photochemical reactions by treatment of wheat seedlings with low concentrations of cadmium: Analysis of electron transport activities and changes in fluorescence yield. Plant Cell Physiol 32:943-951

Baker NR (2008) Chlorophyll fluorescence: a probe of photosynthesis in vivo. Annu Rev Plant Biol 59:89-113

Barros T, Royant A, Standfuss J, Dreuw A, Kühlbrandt W (2009) Crystal structure of plant light-harvesting complex shows the active, energy-transmitting state. EMBO J 28:298-306

Bazzaz MB, Govindjee (1974) Effects of cadmium nitrate on spectral characteristics and light reactions of chloroplasts. Environ Lett 6:1-2

Bouzon ZL, Ferreira EC, dos Santos R, Scherner F, Horta PA, Maraschin M, Schmidt ÉC (2012) Influences of cadmium on fine structure and metabolism of Hypnea musciformis (Rhodophyta, Gigartinales) cultivated in vitro. Protoplasma 249:637-650

Burzynski M, Zurek A (2007) Effects of copper and cadmium on photosynthesis in cucumber cotyledons. Photosynthetica 45:239-244

Chaneva G, Parvanova P, Tzvetkova N, Uzunova A (2010) Photosynthetic response of maize plants against cadmium and paraquat impact. Water Air Soil Pollut 208:287-293

Chugh LK, Sawhney SK (1999) Photosynthetic activities of Pisum sativum seedlings grown in presence of cadmium. Plant Physiol Biochem 37:297-303

Djebali W, Zarrouk M, Brouquisse R, Kahoui ES, Limam F, Ghorbel MH, Chaïbi W (2005) Ultrastructure and lipid alterations induced by cadmium in tomato (Lycopersicon esculentum) chloroplast membranes. Plant Biol 7:358-368

Elhiti M, Yang C, Chan A, Durnin DC, Belmonte M, Ayele BT, Tahir M, Stasolla C (2012) Altered seed oil and glucosinolate levels in transgenic plants overexpressing the Brassica napus shoot meristem less gene. J Exp Bot 63:4447-4461

Fagioni M, D’Amici GM, Timperio AM, Zolla L (2009) Proteomic analysis of multiprotein complexes in the thylakoids membrane upon cadmium treatment. J Proteome Res 8:310-326
Faller P, Kienzler K, Krieger-Liszkay A (2005) Mechanism of $\mathrm{Cd}^{2+}$ toxicity: $\mathrm{Cd}^{2+}$ inhibits photoactivation of photosystem II by competitive binding to the essential $\mathrm{Ca}^{2+}$ site. Biochim Biophys Acta 1706:158-164

Fromme P, Jordan P, Krauss N (2001) Structure of photosystem. Biochim Biophys Acta 1507:5-31

Geiken B, Masojidek J, Rizzuto M, Pompili ML, Giardi MT (1998) Incorporation of S-35 methionine in higher plants reveals that stimulation of the D1 reaction centre II protein turnover accompanies tolerance to heavy metal stress. Plant Cell Environ 21:1265-1273

Gillet S, Decottignies P, Chardonnet S, Le Maréchal P (2006) Cadmium response and redoxin targets in Chlamydomonas reinhardtii: a proteomic approach. Photosynth Res 89:201-211

Goncalves JF, Nicoloso FT, Becker AG, Pereira LB, Tabaldi LA, Cargnelutti D, dePelegrin CMG, Dressler VL, da Rocha JBT, Schetinger MRC (2009) Photosynthetic pigments content, $\delta$-aminolevulinic acid dehydratase and acid phosphatase activities and mineral nutrients concentration in cadmium-exposed Cucumis sativus L. Biologia 64:310-318

Grant CA (2011) Influence of phosphate fertilizer on cadmium in agricultural soils and crops. Agric Agri Food Canada 54:143-155

Gruszecki W, Janik E, Luchowski R, Kernen P, Grudziński W, Gryczyński I (2009) Supramolecular organization of the main photosynthetic antenna complex LHCIl: a monomolecular study. Langmuir 25:9384-9391

Hakmaouia A, Atera M, Bókab K, Barónc M (2007) Copper and cadmium tolerance, uptake and effect on chloroplast ultrastructure studies on Salix purpurea and Phragmites australis. Z Naturforsch C 62:417-426

Hattab S, Dridi B, Chouba L, Kheder MB, Bousetta H (2009) Photosynthesis and growth responses of pea Pisum sativum L. under heavy metals stress. J Environ Sci 21:1552-1556

Jamali MK, Kazi TG, Arain MB, Afridi HI, Jalbani N, Memon AR (2007) Heavy metal contents of vegetables grown in soil, irrigated with mixtures of wastewater and sewage sludge in Pakistan, using ultrasonic-assisted pseudo-digestion. J Agron Crop Sci 193:218-228

Janik E, Maksymiec W, Mazur R, Garstka M, Gruszecki WI (2010) Structural and functional modifications of the major light-harvesting complex II in cadmium or copper-treated Secale cereale. Plant Cell Physiol 51(8):1330-1340

Januškaitienè I (2012) The effect of cadmium on several photosynthetic parameters of pea (Pisum sativum L.) at two growth stages. Agriculture 1 (99):71-76

Kim YY, Yang YY, Lee Y (2002) Pb and Cd uptake in rice roots. Physiol Plant 116:368-372

Küpper H, Šetlík I, Spiller M, Küpper FC, Prášil O (2002) Heavy metal-induced inhibition of photosynthesis: targets of in vivo heavy metal chlorophyll formation. J Phycol 38:429-441

Küpper H, Parameswaran A, Leitenmaier B, Trtílek M, Šetlík I (2007) Cadmiuminduced inhibition of photosynthesis and long-term acclimation to cadmium stress in the hyperaccumulator Thlaspi caerulescens. New Phytol 175:655-674

Latif AA (2008) Cadmium induced changes in pigment content, ion uptake, proline content and phosphoenolpyruvate carboxylase activity in Triticum aestivum seedlings. Aust J Bas App Sci 2:57-62

Liu C, Guo J, Cui Y, Lu T, Zhang X, Shi G (2011) Effects of cadmium and salicylic acid on growth, spectral reflectance and photosynthesis of castor bean seedlings. Plant Soil 344:131-141

López-Millán AF, Sagardoy R, Solanas M, Abadía A, Abadía J (2009) Cadmium toxicity in tomato (Lycopersicon esculentum) plants grown in hydroponics. Environ Exp Botany 65:376-385

Luciński R, Jackowski G (2006) The structure, functions and degradation of pigment-binding proteins of photosystem II. Acta Biochim Pol 53:693-708

Maksymiec W, Krupa Z (2006) The effects of short-term exposition to Cd, excess $\mathrm{Cu}$ ions and jasmonate on oxidative stress appearing in Arabidopsis thaliana. Environ Exp Bot 57:187-194

Malik D, Sheoran IS, Singh R (1992) Carbon metabolism in leaves of cadmium treated wheat seedlings. Plant Physiol Biochem 30:223-229

Mallick N, Mohn FH (2003) Use of chlorophyll fluorescence in metal-stress research: a case study with the green microalga Scenedesmus. Ecotoxicol Environ Saf 55:64-69

Michel KP, Pistorius EK (2004) Adaptation of the photosynthetic electron transport chain in cyanobacteria to iron deficiency: the function of IdiA and IsiA. Physiol Plant 120:36-50

Mobin M, Khan NA (2007) Photosynthetic activity, pigment composition and antioxidative response of two mustard (Brassica juncea) cultivars differing in photosynthetic capacity subjected to cadmium stress. J Plant Physiol 164:601-610 
Morel FMM (2008) The co-evolution of phytoplankton and trace element cycles in the oceans. Geobiology 6:318-324

Mysliwa-Kurdziel B, Strzalka K (2002) Influence of metals on the biosynthesis of photosynthetic pigments. In: Prasad MNV, Strzalka K (eds) Physiology and biochemistry of metal toxicity and tolerance in plants. Springer, Netherlands, pp 201-228

Najeeb U, Jilanic G, Alia S, Sarward M, Xua L, Zhoua W (2011) Insights into cadmium induced physiological and ultra-structural disorders in Juncus effusus L. and its remediation through exogenous citric acid. J Hazard Mater 186:565-574

Nawrot TS, Hecke VE, Thijs L, Richart T, Kuznestsova T, Jin Y, Vangronsveld J, Roels HA, Staessen JA (2006) Environmental exposure to cadmium and risk of cancer: A prospective population-based study. Lancet Oncol 7:119-126

Noriega GO, Balestrasse KB, Batlle A, Tomaro ML (2007) Cadmium induced oxidative stress in soybean plants also by the accumulation of $\delta$ aminolevulinic acid. Biometals 20:841-851

Nouairi I, Ammar WB, Youssef NB, Daoud DBM, Ghorbal MH, Zarrouk M (2005) Comparative study of cadmium effects on membrane lipid composition of Brassica juncea and Brassica napus leaves. Plant Sci 170:511-519

Pacyna JM, Pacyna EG (2001) An assessment of global and regional emissions of trace metals to the atmosphere sources worldwide. Environ Rev 9:269-298

Pagliano C, Raviolo M, Vecchia FD, Gabbrielli R, Gonnelli C, Rascio N, Barbato R, Rocca NL (2006) Evidence for PSII donor-side damage and photoinhibition induced by cadmium treatment on rice (Oryza sativa L.). J Photochem Photobiol B Biol 84:70-78

Perfus-Barbeoch L, Leonhardt N, Vavasseur A, Forestier C (2002) Heavy metal toxicity: cadmium permeates through calcium channels and disturbs the plant water status. Plant J 32:539-548

Perreault F, Dionne J, Didur O, Juneau P, Popovic R (2011) Effect of cadmium on photosystem II activity in Chlamydomonas reinhardtii: alteration of OJIP fluorescence transients indicating the change of apparent activation energies within photosystem II. Photosynth Res 107:151-157

Pietrini F, lannelli MA, Pasqualini S, Massacci A (2003) Interaction of cadmium with glutathione and photosynthesis in developing leaves and chloroplasts of Phragmites australis (Cav.) Trin. ex steudel. Plant Physiol 133(2):829-837

Pietrini F, Zacchini M, lori V, Pietrosanti L, Ferretti M, Massacci A (2010) Spatial distribution of cadmium in leaves and on photosynthesis: examples of different strategies in willow and poplar clones. Plant Biol 12:355-363

Prasad MNV (1995) Cadmium toxicity and tolerance in vascular plants. Environ Exp Bot 35:525-545

Quartacci MF, Pinzino C, Sgherri CLM, Vecchia FD, Navarilzzo F (2000) Growth in excess copper induces changes in the lipid composition and fluidity of PSIIenriched membranes in wheat. Physiol Plant 108:87-93

Remans T, Opdenakker K, Smeets K, Mathijsen D, Vangronsveld J, Cuypers A (2010) Metal-specific and NADPH oxidase dependent changes in lipoxygenase and NADPH oxidase gene expression in Arabidopsis thaliana exposed to cadmium or excess copper. Funct Plant Biol 37:532-544

Santos RW, Schmidt ÉC, Martins RDP, Latini A, Maraschin M, Horta PA, Bouzon ZL (2012) Effects of cadmium on growth, photosynthetic pigments, photosynthetic performance, biochemical parameters and structure of chloroplasts in the agarophyte Gracilaria domingensis (Rhodophyta, Gracilariales). Amer J Plant Sci 3:1077-1084

Sárvári É (2005) Effects of heavy metals on chlorophyll-protein complexes in higher plants: Causes and consequences. In: Pessarakli M (ed) Handbook of photosynthesis. CRC Press, Boca Raton, USA pp, pp 865-888

Sárvári É, Cseh E, Balczer T, Szigeti Z, Záray G, Fodor F (2008) Effect of Cd on the iron re-supply-induced formation of chlorophyll-protein complexes in cucumber. Acta Biol Szeged 52(1):183-186

Sheoran IS, Signal HR, Singh R (1990) Effect of cadmium and nickel on photosynthesis and the enzymes of photosynthetic carbon reduction cycle in pigeon pea (Cajanus cajan L.). Photosynth Res 23:345-351

Shukla UC, Murthy RC, Kakkar P (2008) Combined effect of ultraviolet-B radiation and cadmium contamination on nutrient uptake and photosynthetic pigments in Brassica campestris L. seedlings. Environ Toxicol 23:712-719

Siedlecka A, Baszyński T (1993) Inhibition of electron flow around photosystem I in chloroplasts of $\mathrm{Cd}$-treated maize plants is due to $\mathrm{Cd}$-induced iron deficiency. Physiol Plant 87:199-202

Sigfridsson KGV, Bernat G, Mamedoy F, Styring S (2004) Molecular interference of $\mathrm{Cd}^{2+}$ with photosystem II. Biochim Biophys Acta 1659:19-31

Skrebsky EC, Tabald LA, Pereira B, Rauber R, Maldaner J, Cargnelutti D, Gonçalves JF, Castro GY, Shetinger MRC, Nicoloso FT (2008) Effect of cadmium on growth, micronutrient concentration, and $\delta$-aminolevulinic acid dehydratase and acid phosphatase activities in plants of Pfaffia glomerata. Braz J Plant Physiol 20(4):285-294

Somashekaraiah B, Padmaja K, Prasad A (1992) Phytotoxicity of cadmium ions on germinating seedlings of mung bean (Phaseolus mungo): involvement of lipid peroxides in chlorophyll degradation. Physiol Plant 85:85-89

Stobart AK, Griffith WT, Ameen-Bukhari J, Sherwood RP (1985) The efffect of $\mathrm{Cd}^{2+}$ on the biosynthesis of chlorophyll in leaves of barley. Physiol Plant 63:293298

Tamas L, Dudikova J, Durcekova K, Haluskova L, Huttova J, Mistrik I (2009) Effect of cadmium and temperature on the lipoxygenase activity in barley root tip. Protoplasma 235:7-25

Timperio AM, D'Amici GM, Barta C, Loreto F, Zolla L (2007) Proteomics, pigment composition, and organization of thylakoid membranes in iron-deficient spinach leaves. J Exp Bot 58:3695-3710

UNEP (2010) Final review of scientific information on cadmium. UNEP Chemical Branch, DTIE

Valentoviová K, Halušková L, Huttová J, Mistrík I, Tamás L (2010) Effect of cadmium on diaphorase activity and nitric oxide production in barley root tips. J Plant Physiol 167:10-14

Vassilev A, Lidon F, Scotti P, Da Graca M, Yordanov I (2004) Cadmium-induced changes in chloroplast lipids and photosystem activities in barley plants. Biol Plant 48:153-156

Wahid A, Arshad M, Farooq M (2009) Cadmium phytotoxicity: responses, mechanisms and mitigation strategies. In: Lichtfouse $E$ (ed) Advances in sustainable agriculture, vol 1. Springer, Netherlands, pp 371-403

Wang H, Zhao SC, Liu RC, Zhou W, Jin JY (2009) Changes of photosynthetic activities of maize (Zea mays L.) seedlings in response to cadmium stress. Photosynthetica 47:277-283

Wang F, Chen F, Cai Y, Zhang G, Wu F (2011) Modulation of exogenous glutathione in ultrastructure and photosynthetic performance against $\mathrm{Cd}$ stress in the two barley genotypes differing in Cd tolerance. Biol Trace Elem Res 144(1-3):1275-1288

Wang X, Zhang ZW, Tu SH, Feng WQ, Xu F, Zhu F, Zhang DW, Du JB, Yuan S, Lin HH (2013) Comparative study of four rice cultivars with different levels of cadmium tolerance. Biologia 68:74-81

Wodala B, Eitel G, Gyula TN, Ördög A, Horváth F (2012) Monitoring moderate Cu and $\mathrm{Cd}$ toxicity by chlorophyll fluorescence and P700 absorbance in pea leaves. Photosynthetica 50:380-386

Xue XC, Gao HY, Zhang LT (2013) Effects of cadmium on growth, photosynthetic rate and chlorophyll content in leaves of soybean seedlings. Biol Plant 57 (3):587-590

Ying RR, Qiu RL, Tang YT, Hu PJ, Qiu H, Chen HR, Shi TH, Morel JL (2010) Cadmium tolerance of carbon assimilation enzymes and chloroplast in Zn/ Cd hyperaccumulator Picris divaricata. J Plant Physiol 167:81-87

Zhang M, Senoura T, Yang X, Chao Y, Nishizawa NK (2011) Lhcb2 gene expression analysis in two ecotypes of Sedum alfredii subjected to $\mathrm{Zn} / \mathrm{Cd}$ treatments with functional analysis of SaLhcb2 isolated from a $\mathrm{Zn} / \mathrm{Cd}$ hyperaccumulator. Biotechnol Lett 33:1865-1871

doi:10.1186/1999-3110-54-45

Cite this article as: Parmar et al:: Structural and functional alterations in photosynthetic apparatus of plants under cadmium stress. Botanical Studies 2013 54:45.

\section{Submit your manuscript to a SpringerOpen ${ }^{\circ}$ journal and benefit from:}

- Convenient online submission

- Rigorous peer review

- Immediate publication on acceptance

- Open access: articles freely available online

- High visibility within the field

- Retaining the copyright to your article

Submit your next manuscript at $>$ springeropen.com 